\title{
Erratum to: A Case Study in Balancing Protection, Interpretation, and Public Access in the Treasure Hunting Capital of the World: The Management of the HMS Fowey Shipwreck in Biscayne National Park
}

\author{
Joshua Marano ${ }^{1}$
}

Published online: 8 August 2015

(C) Springer Science+Business Media New York 2015

\section{Erratum to: J Mari Arch DOI 10.1007/s11457-015-9142-3}

On the third and fourth pages of the original article a reference citation was inadvertently omitted.

On the third page, the first sentence of the last paragraph should read as follows:

The District Court's decision, upheld in a subsequent appeal, declared the wreck and its debris were "objects of antiquity," noting also that Klein's "unscientific removal of the artifacts did more to create a marine peril than to prevent one" (Atkins 1983:3; Bright 2010:2).

On the fourth page, the last sentence in the first full paragraph should read as follows:

In an effort to formalize the agreement between the United States and the United Kingdom regarding the stewardship of the wreck site, HMS Fowey became the subject of the NPS's first Memorandum of Understanding concerning the management of a foreignowned historic shipwreck in federal waters (Bright 2010:3; Gadsby and Conlin 2015).

\section{Reference}

Bright J (2010) HMS Fowey: legal case study of a contended submerged cultural resource in Biscayne National Park. Department of History, East Carolina University, Greenville, NC

The online version of the original article can be found under doi:10.1007/s11457-015-9142-3.

Joshua Marano

Joshua_marano@nps.gov

1 Archaeological Technician, Biscayne National Park, 9700 SW 328th St., Homestead, FL 33033, USA 